\title{
Deteksi Brucella abortus dari Sampel Darah-Utuh dengan Uji Polymerase Chain Reaction Tanpa Ekstraksi DNA
}

\section{Detection of Brucella abortus from Whole Blood Samples by Polymerase Chain Reaction Without DNA Extraction}

\author{
David Ardiyanto ${ }^{1}$, Hastari Wuryastuty ${ }^{2 *}$, RadenWasito ${ }^{3}$ \\ ${ }^{1}$ Program Studi Sain Veteriner, Fakultas Kedokteran Hewan, Univesitas Gadjah Mada, Yogyakarta 55281 \\ ${ }^{2}$ Departemen Ilmu Penyakit Dalam, Fakultas Kedokteran Hewan, Universitas Gadjah Mada, Yogyakarta 55281 \\ ${ }^{3}$ Departemen Patologi, Fakultas Kedokteran Hewan, Universitas Gadjah Mada, Yogyakarta 55281 \\ *Corresponding Author, Email: hastari_ugm@yahoo.com
}

Naskah diterima: 17 Januari 2020, direvisi: 29 Januari 2020, disetujui: 20 Nopember 2020

\begin{abstract}
Brucellosis is a zoonotic disease that cause a significant economic losses for cattle industries worldwide. A rapid, precise and accurate diagnosis technique for diagnosis of brucellosis in all stages of the infection is definitely required. Blood-samples are widely used for PCR-based DNA analysis because they are easily collected, handled, and processed. Direct PCR analysis without DNA extraction has been attempted to reduce time and costs for routine analysis. This approach is promising but is still limited by the presence of PCR inhibitors that is naturally found in the blood samples. The objective of this study was to compare the effectivity of direct PCR technique with or without DNA extraction for detection of Brucella abortus in the blood samples. Three whole-blood samples from brucella infected dairy cattle and five whole-blood samples from beef cattle that having abortion were used as samples in this study. A pair of bcsp31 primers and IS711 primers were used for amplification of genus-specific and species-specific of Brucella. The results showed that amplicon in the position of $223 \mathrm{bp}$ and 498 bp that are specific for B. abortus were detected from all of the samples that were analyzed on $1.5 \%$ agarose gels. Based on the result it could be concluded that direct PCR analyses without DNA extraction is a sensitive, specific, simple, rapid and inexpensive assay for detecting B. abortus in the whole blood samples for either dairy or beef cattle and therefore it could improve the existing surveillance and control programs for brucellosis.
\end{abstract}

Key words: brucellosis; direct PCR; PCR inhibitor; whole-blood sample; without DNA extraction

\begin{abstract}
Abstrak
Brucellosis adalah penyakit zoonosis yang menyebabkan kerugian ekonomi yang signifikan bagi industri ternak di seluruh dunia. Teknik diagnosis yang cepat, tepat dan akurat yang dapat digunakan untuk diagnosis brucellosis pada semua tahap infeksi sangat diperlukan. Sampel darah banyak digunakan untuk analisis PCR berbasis DNA karena mudah untuk dikoleksi, ditangani, dan diproses. Metoda PCR langsung tanpa didahului dengan ekstraksi DNA dikembangkan dengan tujuan penghematan waktu dan beaya untuk analisa secara rutin. Tehnik ini sangat menjanjikan tetapi memiliki keterbatasan karena adanya senyawa penghambat PCR yang secara alami terkandung di dalam sampel darah . Tujuan dari penelitian ini adalah membandingkan efektifitas antara uji PCR secara langsung dengan ekstraksi dan tanpa ekstraksi DNA untuk deteksi Brucella abortus di dalam darah. Tiga ( 3 ) sampel darah-EDTA yang berasal dari sapi penderita brucellosis dan 5 sampel darah-EDTA dari sapi potong yang mengalami abortus digunakan sebagai sampel dalam penelitian ini. Pasangan primer bcsp31 dan primer IS711 untuk amplifikasi gen dan species specific digunakan dalam penelitian. Hasil menunjukkan bahwa amplikon/pita pada posisi 223 bp dan 498 bp yang spesifik untuk Brucella abortus terdeteksi dari semua sampel
\end{abstract}


yang dianalisa dengan gel agarosa 1,5\%. Berdasarkan hasil penelitian dapat disimpulkan bahwa uji PCR secara langsung tanpa didahului dengan ekstraksi DNA merupakan tehnik yang sensitif, spesifik, sederhana, cepat dan murah untuk deteksi B. abortus di dalam sampel darah baik sapi perah maupun sapi potong dan oleh karena itu diharapkan dapat digunakan untuk memperbaiki program kontrol dan survailance yang telah ada untuk brucellosis.

Kata kunci : brucellosis; PCR langsung; penghambat PCR; sampel darah-utuh; tanpa ekstraksi DNA

\section{Pendahuluan}

Brucella adalah bakteri Gram negatif intraseluler fakultatif yang menyebabkan brucellosis pada berbagai spesies hewan domestik dan liar di seluruh dunia. Konsekuensi klinis yang disebabkan oleh Brucella spp. secara umum berhubungan dengan masalah reproduksi seperti abortus, retensi plasenta, kawin berulang, kelahiran mati atau kelahiran anak sapi lemah yang mengakibatkan kerugian ekonomi yang tinggi untuk industri sapi baik potong maupun perah (Poester et al., 2013). Kerugian ekonomi lainnya terjadi karena penurunan produksi susu. Pentingnya penyakit menular ini tidak hanya terletak pada kerugian ekonomi bagi ternak tetapi juga risiko terhadap kesehatan manusia karena sifatnya yang zoonosis (Ocholi et al., 2005). Deteksi dini dengan metode analisis yang cepat dan akurat sangat bermanfaat untuk keberhasilan pengendalian penyakit (Mahajan et al., 2017).

Deteksi hewan yang terinfeksi Brucella di dalam sekelompok ternak, secara umum dilakukan secara serologis, khususnya uji Rose Bengal (RBT). Uji RBT untuk brucellosis kurang sensitif karena rendahnya titer antibodi yang dihasilkan terutama di stadium awal dari infeksi (Al-Gharadi et al., 2011; Priyadarshini et al., 2013). Selain itu, uji RBT juga sering menghasilkan reaksi positif palsu, terutama pada sapi yang telah divaksinasi menggunakan vaksin B. abortus galur 19 dan terjadinya reaksi silang dengan mikro-organisme lain seperti Yersinia entero colitica O:9. atau dapat menyebabkan reaksi negatif palsu pada sapi tanpa antibodi terhadap B. abortus. Sapi dengan hasil uji negatif palsu berisiko menjadi sumber penularan penyakit sehingga mengganggu program pengendalian brucellosis. Hal ini disebabkan karena untuk memperoleh hasil diagnosa yang tepat diperlukan uji ulang setiap 10 hingga 14 hari selama periode minimal 3 bulan setelah uji yang pertama (Karthik et al., 2014; DaSilva Moi et al., 2012; El-Diasty et al., 2018). Hingga saat ini, metode isolasi masih merupakan gold standard untuk deteksi mikroorganisme yang hidup di dalam darah seperti brucella karena spesifisitas nya yang tinggi. Meskipun demikian, untuk mikro-organisme intraseluler yang pertumbuhannya lambat seperti Brucella metode isolasi memiliki sensitivitas yang rendah dan memiliki risiko terjadinya penularan penyakit kepada laboran karena bersifat zoonotik sehingga diperlukan fasilitas biosafety level 3 dan ketrampilan teknis yang tinggi untuk penanganan sampel (Solmaz et al., 2014; DaSilva Moi et al., 2012). Karena permasalahan tersebut maka tehnik pengujian berbasis asam nukleat tanpa isolasi bakteri telah dikembangkan untuk identifikasi brucella selama 20 tahun terakhir (Afshari et al., 2012).

Hingga saat ini Polymerase Chain Reaction (PCR) telah berhasil digunakan untuk deteksi brucella dari berbagai jenis sampel seperti serum (Thorat et al., 2017; Parthiban et al., 2019), susu (Noor et al., 2015), buffy coat, semen dan darahutuh (Khamesipour et al., 2013; Wuryastuty et al., 2019). Menurut Zerva et al. (2001), darahutuh atau serum merupakan sampel terbaik untuk deteksi dan diagnosis berbagai penyakit infeksius termasuk brucella. Hal ini disebabkan karena darah-utuh dan serum merupakan sampel yang relatif mudah untuk dikoleksi, ditangani dan diproses serta memiliki risiko yang lebih rendah sehingga direkomendasikan untuk digunakan dalam diagnosis brucellosis. Selain itu, proses ekstraksi DNA dari sampel darah-utuh maupun serum juga lebih mudah dibandingkan dengan ekstraksi DNA dari jaringan (Thorat et al., 2017; Wuryastuty et al., 2019). Meskipun tehnik ekstraksi DNA yang telah dikembangkan oleh para ahli dan tersedia secara komersial adalah efektif, tetapi secara umum dapat mengakibatkan berkurangnya jumlah atau bahkan hilangnya sampel DNA yang penting dan memiliki potensi timbulnya kesalahan penguji dalam pencampuran 
sampel atau terjadinya kontaminasi silang antar sampel.

Saat ini metode amplifikasi tanpa ekstraksi (pemurnian) DNA dari berbagai jenis sampel seperti darah-utuh, tanaman, jaringan hewan atau manusia telah dikembangkan dan berbagai perangkatnya telah tersedia secara komersial (Biswas et al., 2013). Metode ini menawarkan cara yang lebih baik untuk mengurangi waktu penanganan sampel, dana yang diperlukan untuk pemurnian template (cetakan) dan risiko penyebaran mikroorganisme infeksius seperti Brucella spp. Tujuan dari penelitian ini adalah mempelajari efektifitas amplifikasi DNA dengan atau tanpa ekstraksi dalam mendeteksi Brucella abortus dari sampel darah-utuh. Hal ini penting karena tehnik baru ini diharapkan memperpendek waktu pemrosesan sampel, risiko kontaminasi silang antar sampel, mengurangi risiko penguji terinfeksi bakteri yang zoonotik dengan harga yang relatif lebih murah dibandingkan dengan tehnik yang memerlukan ekstraksi DNA.

\section{Materi dan Metode}

Pada penelitian ini, sekitar $3 \mathrm{ml}$ sampel darah utuh diambil melalui vena coccygeal menggunakan tabung vakum berlapis Ethylene diamine tetra acetic acid (EDTA, BecktonDickensen) dari 3 sapi perah penderita brucellosis dari daerah Jawa Tengah. Setiap sampel darah utuh kemudian dibagi menjadi dua bagian: 1. DNA dari sampel darah utuh diekstraksi sebelum dilakukan uji PCR dan 2. DNA dalam sampel darah utuh diamplifikasi secara langsung dengan uji PCR tanpa dilakukan ekstraksi DNA.

Pada penelitian ini, untuk konfirmasi reproduktifitas dan penerapan dari uji PCR langsung yang dikembangkan, 5 sampel darah-EDTA dari sapi potong penderita abortus diikut sertakan dalam analisis dengan cara yang sama (tanpa ekstraksi DNA). Semua sapi berasal dari daerah Jawa Tengah. (Keterangan Kelaikan Etik: 0104/ EC-FKH/Int/2019).

Ekstraksi DNA. Semua sampel darah utuh diekstraksi menggunakan perangkat untuk pemurnian DNA Genomik GeneJet yang tersedia secara komersial (Thermo Fisher Scientific, Waltham, Massachusetts, Amerika). Empat ratus mikroliter bufer pelisis dan $20 \mu$ larutan
Proteinase K ditambahkan ke dalam setiap tabung eppendorf yang berisi $200 \mu \mathrm{l}$ sampel darah utuh. Semua larutan dalam tabung dicampur secara merata dengan cara di vorteks dan diinkubasi pada suhu $56^{\circ} \mathrm{C}$ selama 10 menit. Setelah inkubasi, $200 \mu \mathrm{l}$ larutan etanol absolut ditambahkan ke dalam setiap tabung. Campuran larutan kemudian dipindahkan kedalam kolom GeneJET Genomic DNA Purification yang telah disiapkan dengan cara dipasangkan ke dalam tabung pengumpul dan disentrifugasi selama 1 menit pada kecepatan 6000xg. Setelah sentrifugasi, filtrate dibuang dan kolom pemurnian ditempatkan ke dalam tabung pengumpul baru. Lima ratus mikroliter bufer pencuci I ditambahkan kedalam kolom diikuti dengan sentrifugasi selama 1 menit pada kecepatan 8000xg. Setelah sentrifugasi, filtrat dibuang dan kolom pemurnian ditempatkan kembali ke dalam tabung pengumpul. Lima ratus mikroliter bufer pencuci II ditambahkan kedalam kolom diikuti dengan sentrifugasi selama 3 menit pada kecepatan maksimum $(\geq 12000 \mathrm{xg})$. Setelah sentrifugasi, filtrat dan tabung pengumpul dibuang dan kolom pemurnian dipindahkan ke tabung eppendorf $1,5 \mathrm{ml}$ steril. Dua ratus mikroliter bufer elusi ditambahkan ke bagian tengah membran kolom GeneJET Genomic DNA Purification, diinkubasi selama 2 menit pada suhu kamar dilanjutkan dengan sentrifugasi pada $8000 x g$ selama 1 menit untuk mengelusi genom DNA.

Polymerase Chain Reaction. Deteksi molekuler B. abortus dengan atau tanpa ekstraksi DNA brucella dilakukan dengan menggunakan pasangan primer spesifik untuk amplifikasi gen bcsp31 (Bailey et al., 1992) dan primer spesifik untuk amplifikasi gen IS711 (Doust et al., 2007) .

Amplifikasi ekstrak DNA brucella dikerjakan dalam volume total $50 \mu 1$. Ke dalam setiap tabung PCR $200 \mu$, campuran reaksi yang mengandung $25 \mu \mathrm{l}$ GoTaq ${ }^{\circledR}$ Green Master Mix $2 \mathrm{x}$ (Promega, Madison, WI 53711-5399 USA), 2.5 $\mu 110 \mathrm{pMol}$ primer forward dan $2.5 \mu 110 \mathrm{pMol}$ primer reverse (Tabel 1.), $5 \mu$ l sampel DNA dan $\mathrm{H}_{2} \mathrm{O}$ bebas nuklease ditambahkan sampai volume total menjadi $50 \mu \mathrm{l}$. Tabung PCR kemudian ditempatkan ke dalam mesin Personal Combi Thermocycler Biometra (37079 Goettingen Jerman) untuk diamplifikasi dengan kondisi siklik seperti dijelaskan dalam Tabel 2. Produk 
amplifikasi PCR dianalisis dengan elektroforesis pada ultrapure agarose gel ${ }^{\mathrm{TM}}$ (Invitrogen) $1,5 \%$ dengan kecepatan $120 \mathrm{~V} 400$ A selama 45 menit. Gel agarosa kemudian direndam di dalam larutan Tris-borate-EDTA ${ }^{\mathrm{TM}}$ (Sigma-Aldrich) bufer $1 \mathrm{x}$ ditambah dengan $0,5 \mu \mathrm{g} / \mathrm{ml}$ larutan ethidium bromida $^{\mathrm{TM}}$ (Sigma-Aldrich) selama 15 menit. Produk elektroforesis yang telah diwarnai kemudian divisualisasi menggunakan UV transiluminator dan direkam menggunakan Gel Logic 100 Imaging System (Kodak, Carestream Health Inc. Rochester, NY 14608).

Amplifikasi DNA tanpa ekstraksi dilakukan menggunakan Thermo ScientificTMPhusionTM Blood Direct PCR Master Mix (ThermoFisher Scientific Inc., Austria / UK). Total volume setiap campuran yang ditambahkan ke setiap tabung PCR adalah $50 \mu$ l. Bahan-bahan yang digunakan dalam campuran terdiri dari: $25 \mu \mathrm{l} 2 \mathrm{x}$ Phusion Blood Direct campuran utama PCR, 1,5 $\mu \mathrm{l} 20 \mathrm{pMol}$ primer forward dan $1,5 \mu 120 \mathrm{pMol}$ primer reverse khusus untuk gen brucella atau $B$. spesies abortus dalam urutan basa seperti pada Tabel 1 ., 1,5 $\mu 150$ $\mathrm{mM} \mathrm{MgCl2,} 2.5 \mu 150 \mathrm{mM}$ EDTA, $2.5 \mu 1$ DMSO, $10 \mu \mathrm{l}$ darah utuh dan $\mathrm{H}_{2} \mathrm{O}$ bebas nuklease hingga total volume menjadi $50 \mu \mathrm{l}$. Kondisi siklus untuk amplifikasi dilakukan sebagaimana tercantum dalam Tabel 3.

\section{Hasil dan Pembahasan}

Gambar 1 dan 2 menunjukkan produk PCR hasil amplifikasi DNA brucella dari darah-utuh sapi perah penderita Brucellosis menggunakan pasangan primer yang spesifik untuk amplifikasi gen Brucella spp. atau primer yang spesifik untuk amplifikasi spesies Brucella abortus. Hasil penelitian menunjukkan bahwa DNA Brucella abortus dari sampel darah yang sama berhasil diamplifikasi baik dengan atau tanpa dilakukan ekstraksi DNA sebelum dianalisa dengan tehnik PCR. Hasil konfirmasi tehnik PCR secara langsung tanpa ekstraksi DNA dari sampel darah

Tabel 1. Untaian basa primer untuk Brucella abortus dalam penelitian ini.

\begin{tabular}{|c|c|c|c|c|}
\hline Primer & Forward $\left(5^{\prime} \rightarrow 3^{\prime}\right)$ & Reverse $\left(5^{\prime} \rightarrow 3^{\prime}\right)$ & PCR Product & Ref. \\
\hline Brucella spp. (bcsp31) & TGGCTCGGTTGCCAATATCAA & CGCGCTTGCCTTTCAGGTCTG & $223 \mathrm{bp}$ & Baily et al. 1992 \\
\hline Brucella abortus (IS711) & TGCCGATCACTTAAGGGCCTTCAT & GACGAACGGAATTTTTCCAATCCC & 498 bp & Doust et al. 2007 \\
\hline
\end{tabular}

Tabel 2. Protokol siklus PCR untuk amplifikasi Brucella abortus dengan ekstraksi DNA

\begin{tabular}{|c|c|c|c|c|c|}
\hline \multirow{2}{*}{ Target Gen } & \multirow{2}{*}{ Produk PCR } & \multicolumn{3}{|c|}{ Kondisi Siklus } & \multirow{2}{*}{ Jumlah Siklus } \\
\hline & & Langkah & Suhu & Waktu & \\
\hline \multirow[t]{5}{*}{$B C S P 31$} & $223 \mathrm{bp}$ & Initial Denaturation & $95^{\circ} \mathrm{C}$ & $5 \mathrm{~min}$. & 1 \\
\hline & & Denaturation & $94^{\circ} \mathrm{C}$ & $1 \mathrm{~min}$. & \\
\hline & & Annealing & $55^{\circ} \mathrm{C}$ & $1 \mathrm{~min}$. & $40 \mathrm{x}$ \\
\hline & & Extension & $72^{\circ} \mathrm{C}$ & $1 \mathrm{~min}$. & \\
\hline & & Final Extension & $72^{\circ} \mathrm{C}$ & $5 \mathrm{~min}$. & 1 \\
\hline \multirow[t]{5}{*}{$1 \mathrm{~S} 711$} & 498bp & Initial Denaturation & $95^{\circ} \mathrm{C}$ & $5 \mathrm{~min}$. & 1 \\
\hline & & Denaturation & $95^{\circ} \mathrm{C}$ & $30 \mathrm{sec}$. & \\
\hline & & Annealing & $58^{\circ} \mathrm{C}$ & $30 \mathrm{sec}$. & $35 \mathrm{x}$ \\
\hline & & Extension & $72^{\circ} \mathrm{C}$ & $30 \mathrm{sec}$. & \\
\hline & & Final Extension & $72^{\circ} \mathrm{C}$ & $5 \mathrm{~min}$. & 1 \\
\hline
\end{tabular}

Tabel 3. Protokol siklus PCR untuk amplifikasi Brucella abortus tanpa ekstraksi DNA

\begin{tabular}{|c|c|c|c|c|c|}
\hline \multirow{2}{*}{ Target Gen } & \multirow{2}{*}{ Produk PCR } & \multicolumn{3}{|c|}{ Kondisi Siklus } & \multirow[t]{2}{*}{ Jumlah Siklus } \\
\hline & & Langkah & Suhu & Waktu & \\
\hline \multirow[t]{5}{*}{$\begin{array}{c}\text { BCSP31 atau } \\
\text { B. abortus (IS711) }\end{array}$} & 223bp atau 498bp & Lysis of cells & $98^{\circ} \mathrm{C}$ & $5 \mathrm{~min}$. & 1 \\
\hline & & Denaturation & $98^{\circ} \mathrm{C}$ & $1 \mathrm{sec}$ & \\
\hline & & Annealing & $60^{\circ} \mathrm{C}$ & $5 \mathrm{sec}$ & $40 x$ \\
\hline & & Extension & $72^{\circ} \mathrm{C}$ & $15 \mathrm{sec}$ & \\
\hline & & Final Extension & $72^{\circ} \mathrm{C}$ & $1 \mathrm{~min}$ & 1 \\
\hline
\end{tabular}


utuh yang dikoleksi dari sapi potong penderita abortus memberikan hasil yang sama.

Brucellosis merupakan penyakit yang rumit dalam hal diagnosis. Hingga saat ini uji serologis terutama Rose bengal test (RBT) merupakan metode pilihan di seluruh laboratorium di Indonesia karena sensitivitas dan spesifisitasnya yang relative tinggi sehingga digunakan sebagai skrining awal adanya brucellosis pada ternak. Complement Fixation Test (CFT) merupakan uji serologis yang memiliki sensitivitas dan spesifisitas lebih baik dibandingkan dengan uji RBT sehingga umum digunakan sebagai uji konfirmasi. Namun demikian, dalam kondisi lapangan, CFT mungkin menunjukkan sensitivitas yang lebih rendah dibandingkan dengan RBT, yang membuatnya handal di tingkat kelompok tetapi bersifat terbatas pada tingkat individual. Sensitivitas CFT secara langsung juga berkaitan dengan tahapan infeksi dari hewan yang diuji, dengan nilai yang lebih



Gambar 1. Produk PCR dari Brucella spp. positif sampel (223 bp) dengan ekstraksi DNA (Pita 2, 2, 4) dan tanpa ekstraksi DNA (Pita 6, 7, 8); Penanda DNA SMOBIO 100bp (Pita 5) dan kontrol negatif (Pita 1). Sampel berasal dari sapi perah positif terinfeksi $B$. abortus secara serologis dan molekuler.

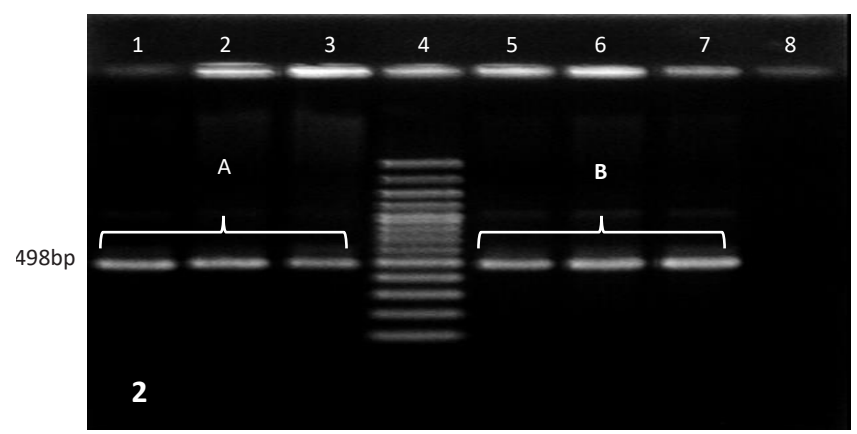

Gambar 2. Produk amplifikasi PCR dari Brucella abortus positif sampel (498 bp) dengan ekstraksi DNA (Pita 1, 2, 3) dan tanpa ekstraksi DNA (Pita 5, 6, 7); Penanda DNA SMOBIO 100bp (Pita 4) dan kontrol negatif (Pita 8). Sampel berasal dari sapi perah positif terinfeksi $B$. abortus secara serologis dan molekuler.

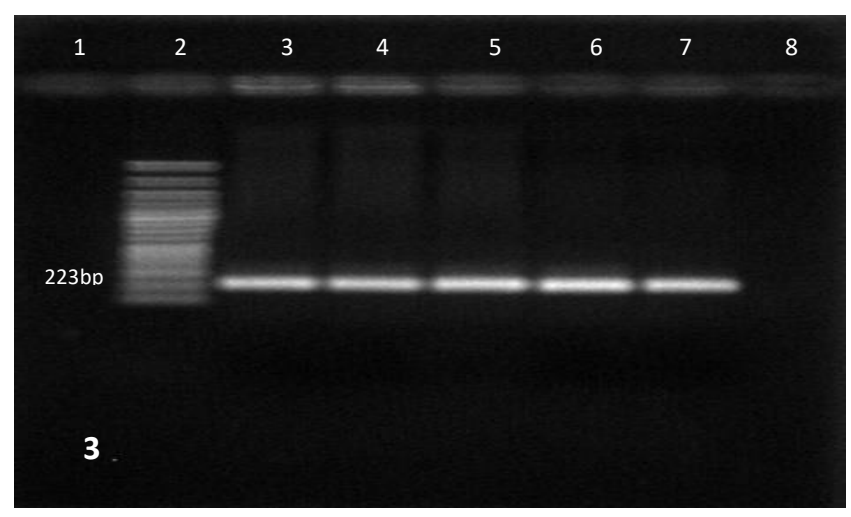

Gambar 3. Hasil amplifikasi PCR secara langsung tanpa ekstraksi DNA dari sampel darah-utuh yang dikoleksi dari sapi potong penderita abortus menggunakan primer spesifik untuk gen Brucella spp. (223bp). Pita 2: Penanda DNA SMOBIO 100bp; Pita 3 - 7: Sampel Lapangan positif Brucella spp.; Pita 8: Kontrol negatif.

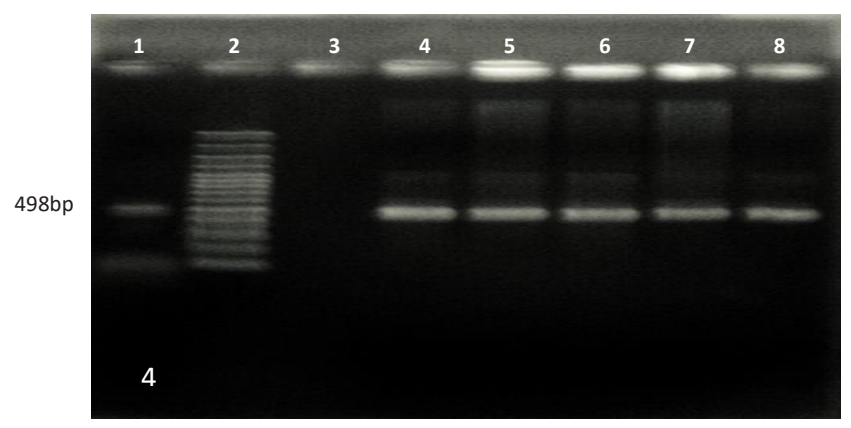

Gambar 4. Hasil amplifikasi PCR secara langsung tanpa ekstraksi DNA dari sampel darah-utuh yang dikoleksi dari sapi potong penderita abortus menggunakan primer spesifik untuk B.abortus (498bp). Pita 1: Kontrol positif ; Pita 2: Penanda DNA SMOBIO 100bp; Pita 3: Kontrol negatif; Pita 4 - 8: Sampel lapangan positif B.abortus.

tinggi untuk hewan dalam fase infeksi akut dibandingkan dengan hewan yang terinfeksi secara kronis. Berdasarkan hal tersebut, tidak ada uji serologis tunggal yang dapat digunakan untuk menetapkan diagnosa brucellosis di semua tahapan infeksi. Di beberapa situasi, hasil uji RBT mungkin positif tetapi uji CFT memberikan hasil yang negatif (Fensterbank, 1986).

Kondisi tersebut dapat terjadi setelah hewan divaksinasi dengan vaksin brucella galur 19 atau adanya reaksi silang setelah hewan terinfeksi dengan mikro-organisme lain seperti Francisella tularensis, Escherichia coli O:157, E. Coli O:116 dan Yersinia enterocolitica O:9. Serum dari hewan yang divaksinasi dengan vaksin brucella galur RB51 tidak memberikan reaksi dengan uji RBT atau CFT, tetapi, dengan uji ELISA, antibodi dari sapi yang divaksinasi dengan vaksin brucella 
galur RB51 tidak selalu dapat dibedakan dengan antibodi akibat infeksi secara alami (OIE, 2018).

Beberapa peneliti telah memanfaatkan uji PCR dalam deteksi brucellosis dalam serum dan sampel darah utuh dan berhasil mengamplifikasi patogen yang ada di dalam sirkulasi darah. Uji PCR konvensional memiliki sensitivitas dan spesifisitas tinggi dan dapat mendeteksi terjadinya infeksi pada tahap yang lebih awal bila dibandingkan dengan uji serologis, serta memiliki hubungan yang erat ( $>90 \%$ ) dengan hasil uji realtime PCR untuk deteksi antigen Brucella abortus (Wuryastuty et al., 2019) maupun Brucella mellitensis (Al-Gharadi et al., 2011).

Masalah dalam penggunaan darah sebagai sampel untuk uji PCR terletak pada berbagai senyawa penghambat yang secara alami terkandung di dalam sampel darah maupun senyawa penghambat lain yang diperoleh selama proses pengambilan sampel, pemrosesan sampel maupun selama ekstraksi asam nukleat (Schrader et al., 2012). Secara umum, sampel darah disimpan di dalam tabung yang berlapis antikoagulan. Antikoagulan yang umum digunakan antara lain sodium heparin, lithium heparin, sodium citrate dan EDTA. Untuk sampel darah utuh, pilihan jenis antikoagulan sangat penting karena masing-masing memiliki dampak negatif terhadap amplifikasi PCR secara langsung. Menurut Konet et al. (2000) dan Costafreda et al. (2006), hambatan oleh heparin terjadi secara langsung terhadap RNA atau DNA yang berasal dari plasma dan bukan RNA atau DNA yang berasal dari sel darah putih serta bukan hambatan terhadap enzim dari reaksi.

Pada penelitian ini, antikoagulan yang digunakan adalah EDTA. Pemilihan jenis antikoagulan dalam penelitian ini didasarkan pada hasil penelitian yang dilakukan oleh Sidstedt et al. (2018). Menurut Li et al. (2011), penghambatan aktivitas DNA polimerase oleh EDTA berhubungan dengan kemampuannya mengkelat $\mathrm{Mg}^{2+}$, sementara kelarutan DNA bervariasi tergantung konsentrasi EDTA dan $\mathrm{NaCl}$. Lebih lanjut dikatakan bahwa untuk amplifikasi PCR secara langsung tanpa ekstraksi DNA, diperlukan konsentrasi EDTA dan $\mathrm{NaCl}$ hingga 2,0 mM untuk hasil yang optimal. Setiap tabung berlapis EDTA mengandung 1,2-2,0 mM EDTA/ml darah.
Volume darah yang digunakan pada penelitian ini adalah $10 \mu \mathrm{l}(20 \%)$ untuk setiap $50 \mu \mathrm{l}$ reaksi PCR, sehingga untuk setiap siklus reaksi mengandung sekitar 0,4 mM EDTA. Sidstedt et al. (2015) membuktikan bahwa efek penghambatan EDTA baru terjadi jika konsentrasi EDTA mencapai 6-18 mM/reaksi. Hasil pada Gambar 1, 2, 3 dan 4 menunjukkan bahwa amplikon PCR terdeteksi secara jelas pada $1,5 \%$ gel agarosa membuktikan tidak adanya hambatan oleh EDTA.

Menurut Opel et al. (2010) ada tiga mekanisme dasar penghambatan PCR yaitu: 1 . Pengikatan DNA, 2. Pengikatan enzim polimerase dan 3. Mode campuran yaitu inhibitor yang berpengaruh terhadap kerja enzim polimerase maupun DNA. Menurut Vilahur et al. (2013), pada prinsipnya, semakin segar sampel semakin baik kualitas RNA dan DNA yang akan diperoleh. Ketika berhadapan dengan sampel klinis, perlu diperhatikan waktu dan suhu penyimpanan sampel sejak dikumpulkan hingga dilakukan pemurnian baik RNA maupun DNA. Hasil penelitian Huang et al. (2017) memberi petunjuk tentang waktu dan suhu penyimpanan darah utuh untuk diperoleh DNA atau RNA yang berkualitas tinggi sesuai dengan uji yang akan dikerjakan. Untuk uji sekuensing, waktu penyimpanan maksimum dari sampel darah utuh adalah 24 jam sedangkan untuk uji microarray lama penyimpanan sampel bias sampai 32 jam. Meskipun demikian, penyimpanan pada suhu rendah tidak selalu menjamin sampel dari kerusakan. Penyimpanan sampel darah utuh di dalam freezer secara signifikan akan merusak RNA. Secara umum, sampel DNA dapat bertahan di dalam sel darah utuh hingga 15 hari tetapi metilasi DNA secara signifikan mulai mengalami perubahan sesudah sampel disimpan di dalam almari pendingin lebih dari 3 hari. Selain itu jumlah DNA juga akan mengalami penurunan seiring dengan peningkatan terjadinya lisis dari sel darah putih. Berdasarkan hal yang dijelaskan sebelumnya, sampel yang digunakan pada penelitian ini semuanya disimpan di dalam almari pendingin dengan waktu penyimpanan tidak lebih dari 3 hari sejak sampel dikoleksi hingga pelaksanaan uji.

Hemoglobin dan imunoglobulin $\mathrm{G}$ adalah dua inhibitor PCR utama dalam darah, di mana hemoglobin berpengaruh terhadap proses amplifikasi 
melalui efek langsung pada aktivitas DNA polimerase sedangkan immunoglobulin $\mathrm{G}$ akan mengikat DNA genom rantai tunggal sehingga proses polimerisasi DNA dalam beberapa siklus awal PCR akan terhambat (Sidstedt et al., 2018). Untuk tehnik qPCR, penggunaan darah utuh berpengaruh terhadap amplifikasi dan deteksi fluoresensi (Sidstedt et al., 2015). Tahapan pencucian secara berulang pada metode ekstraksi juga dilaporkan dapat mengurangi jumlah faktor penghambat seperti hemoglobin. Namun demikian proses pencucian dapat secara signifikan menurunkan jumlah DNA yang dimurnikan sehingga beresiko menimbulkan terjadinya hasil negatif palsu. Konsentrasi DNA $(\mu \mathrm{g} / \mathrm{ml})$ dapat diukur menggunakan spektrofotometer Qubit sesudah dilakukan ekstraksi, seperti yang dilakukan pada penelitian ini.

Dari beberapa hasil penelitian sebelumnya, mekanisme kerja dari senyawa-senyawa aktif yang terkandung di dalam perangkat yang tersedia secara komersial dipercaya mengakibatkan netralisasi zat penghambat yang bertanggung jawab terjadinya pengikatan terhadap enzim DNA polimerase dan/atau cetakan DNA. Terikatnya faktor penghambat oleh senyawa di dalam perangkat akan membebaskan enzim DNA polimerase dan/atau cetakan DNA untuk digunakan dalam proses amplifikasi (Biswas et al., 2013). Pada prinsipnya efektifitas uji PCR secara langsung terletak pada penggunaan sampel DNA yang berkualitas tinggi dan enzim DNA polymerase yang resisten terhadap faktor penghambat yang terkandung di dalam sampel darah merupakan solusinya (Miura et al., 2013; Werblow et al., 2016).

\section{Kesimpulan}

Berdasarkan hasil penelitian dapat disimpulkan bahwa uji amplifikasi PCR menggunakan sampel darah utuh tanpa didahului ekstraksi DNA merupakan uji yang sensitif, spesifik, sederhana, cepat dan hemat beaya untuk diagnosa brucellosis pada sapi perah maupun sapi potong dan oleh karena itu diharapkan dapat digunakan untuk memperbaiki program kontrol dan survailance yang telah ada.

\section{Ucapan Terima Kasih}

Penulis berterimakasih kepada: 1. Direktorat Riset Dan Pengabdian Masyarakat Direktorat
Jenderal Penguatan Riset Dan Pengembangan Kementerian Riset, Teknologi, Dan Pendidikan Tinggi dan Universitas Gadjah Mada atas dukungan dana melalui Penelitian Dasar Unggulan Perguruan Tinggi, sesuai dengan Perjanjian Pendanaan Penelitian Dan Pengabdian Kepada Masyarakat Tahun Anggaran 2018 (Nomor 199/ UN1/DITLIT/DIT-LIT/LT/2018). 2. Drh. Aldi Salman yang telah berbaik hati untuk berbagi sampel darah dari sapi perah penderita brucellosis sebelum dilakukan tindak pemotongan bersyarat.

\section{Daftar Pustaka}

Afshari, A., Schrenzel, J., Ieven, M. and Harbath, S. (2012). Bench-to-bedside review: Rapid molecular diagnostics for bloodstream infection a new frontier? Critical Care : $1-12$.

Al-Garadi, M.A., Khairani-Bejo, S,m Zunita, Z. and Omar, A.R. (2011). Detection of Brucella mellitensis in blood samples collected from goats. Journal of Animal and Veterinary Advances. 10(11): 1437-1444.

Bailey, G.G., Krahn, J.B. and Drasar, B.S. (1992). Detection of Brucella mellitensis and Brucella abortus by DNA amplification. American Journal of Tropical Medicine and Hygiene. 95: 271-275.

Biswas, C., Dey, P. and Satpathy, S. (2013). A method of direct PCR without DNA extraction for rapid detection of begomoviruses infecting jute and mesta. Letters in Applied Microbiology. 58: 350355.

Costafreda, M.I., Bosch, A. and Pinto, R.M. (2006). Development, evaluation and standardization of a real-time TaqMan reverse transcription $\mathrm{PCR}$ assay for quantification of hepatitis $\mathrm{A}$ virus in clinical and shelfish samples. Applied and Environmental Microbiology 6: 3846-3855.

Da Silva Moi, J.P., Araujo, F.S. and Paixao, T.A. (2012). Laboratorial diagnosis of animal brucellosis. Revista Brasileira Ciencia Veterinaria. 19: 117-126.

Doust, S.R.H., Ahmadi, Z. and Ahmadi, A. (2007). Detection of Brucella abortus by alkB and 
IS711 based primers. Journal of Research in Medical Science. 12: 62-67.

El-Diasty, M., Wareth, G., Melzer, F., Mustafa, S., Sprague, L.D. and Neubauer, H. (2018). Isolation of Brucella abortus and Brucella melitensis from seronegative Cows is a serious impediment in Brucellosis control. Veterinary Science. 5(28):1-4.

Fensterbank, R. 1986. Brucellosis in cattle, sheep and goats: diagnosis, control and vaccination. Revue scientifique et technique (International Office of Epizootics).5(3): 605-618.

Huang, L-H., Lin, P-H., Tsai, K-W., Wang, L-J., Huang, Y-H., Kuo, H-C. and Li, S-C. (2017). The effects of storage temperature and duration of blood samples on DNA and RNA qualities. Plos One: 1-13.

Karthik, K., Rathore, R., Thomas, P., Elamurugan, A., Arun, T.R. and Dhama, K. (2014). Serological and molecular detection of Brucella abortus from cattle by RBPT, STAT and PCR and sample suitability of whole blood for PCR. Asian Journal of Animal and Veterinary Advances. 9(4): 262-269.

Khamesipour, F., Doosti, A. and Taheri, H. (2013). Molecular detetion of brucella spp. In the semen, testis and blood samples of cattle and sheep. Journal of Pure Applied Microbiology. 7: 495-500.

Konet, D.S., Mezencio, J.M., Babcock, G. and Brown, F. (2000). Inhibitors of RT-PCR in serum. Journal of Virological Methods. 84: 95-98.

Li, H., Xu, H., Zhao, C., Sulaiman, Y. and Wu, C. (2011). A PCR amplification method without DNA extraction. Electrophoresis. 32: 394-397.

Mahajan, V., Banga, H.S. and Vilia, G. (2017). Comparison of diagnostic tests for the detection of bovine brucellosis in the natural cases of abortion. Iranian Journal of Veterinary Research. 18: 183-189.

Miura, M., Tanigawa, C., Fujii, Y. and Kaneko, S. (2013). Comparison of six commerciallyavailable DNA Polymerase for diract PCR.
Revista do Instituto de Medicina Tropical de Sao Paulo. 55(6): 401-406.

Noor, S.M., Sudarmono, P.P., Kusumawati, A. and Karuniawati, A. (2015). Deteksi Brucelosis pada susu sapi dengan uji Polymerase Chain Reaction. Jurnal Kedokteran Hewan. 9 (1): 64-66.

Ocholi, R.A., Kwaga, J.K.P., Ayogi, I. and Bale, J.O.O. (2005). Abortion due to Brucella abortus in sheep in Nigeria. Revue Scientifique et Technique International Office of Epizootics.24: 973-979.

Office International des Epizooties. (2018). Bovine Brucellosis In Manual of Diagnostic Tests and Vaccines for Terrestrial Animals. $8^{\text {th }}$ Edition. OIE. World Organization for Animal Health

Opel, K.L., Chung, D. and McCord, B.R. (2010). A study of PCR inhibition mechanisms using real time PCR. Journal of Forensic Science. 55: 25-33.

Parthiban, S., Prabhu, M.,Anne, N.S., Malmarugan, S. and Rajeswar, J.J. (2019). Serum based screening and molecular detection of brucellosis in ruminants. Indian Journal of Biotechnology. 18: 22-25.

Poester, F.P., Samartino, L.E. and Santos, R.L. (2013). Pathogenesis and pathobiology of brucellosis in livestock. Revue Scientifique et Technique International Office of Epizootics. 32(1): 105-115.

Priyadarshini, A., Sarangi, L.N. and Palai, T.K. (2013). Brucellosis in cattle and occupationally exposed human beings: A serosurveys in Odisha, India. Journal of Pure and Applied Microbiology. 7: 32553260 .

Schrader, C., Schielke, A., Ellerbroek, L. and Johne, R. (2012). PCR inhibitors-occurrence, properties and removal. Journal of Applied Microbiology. 113: 1014-1026.

Sidstedt, M., Jansson, L., Nilsson, E., Noppa, L., Forsman, M., and Radstrom, P. (2015). Humic substances cause fluorescence inhibition in real-time polymerase chain reaction. Analytical Biochemistry. 487: 30-37. 
Sidstedt, M., Hedman, J., Romsos, E.L., Waitara, L., Wadso, L., Steffen, C.R., Vallone, P.M. and Radstrom, P. (2018). Inhibition mechanism of hemoglobin, immunoglobulin G, and whole blood in digital and real-time PCR. Analytical and Bioanalytical Chemistry. 410: 2569-2583.

Solmaz, H., Cantekin, Z., Altug, N., Ilhan, Z., Aslan, S. and Ergun, Y. (2014). A PCR method with internal control for detection of Brucella spp. from bovine abortion samples. Revue de Medecine Veterinaire 165, 9-10: 253-257.

Thorat, V.D., Bannalikar, A.S., Doiphode, A., Majee, S.B., Gandge, R.S. and Ingle, S.A. (2017). Isolation, identification and molecular detection of Brucella abortus from cattle and buffalo. International Journal of Current Microbiology and Applied Sciences. 6(10): 2853-2864.

Vilahur, N., Baccarelli, A.A., Bustamante, M., Agramunt, S., Byun, H.M. and Femandez, M.F. (2013). Storage conditions and stability of global DNA methylation in placental tissue. Epigenomics 5(3): 341-348.
Werblow, A., Flechl, E., Klimpel, S., Zittra, C., Lebl, K., Kieser, K., Laciny, A., Silbermayr, K., Melaun, C. and Fuehrer, H.P. (2016). Direct PCR of indigenous and invasive mosquito species: a time- and cost-effective technique of mosguito barcoding. Medical and Veterinay Entomology. 30: 8-13.

Wuryastuty, H., Wasito, R. and Sugiyono. (2019). Molecular identification of Brucella abortus collected from whole blood samples of seronegative dairy cattle with reproductive disorders in Central Java, Indonesia. Pakistan Veterinary Journal. 39(3): 455458.

Zerva, L., Bourantas, K., Mitka, S., Kansouzidou, A. and Legakis, N.J. (2001). Serum is the preferred clinical specimen for diagnosis of human brucellosis by PCR. Journal of Clinical Microbiology. 39(4): 1661-1664. 